\title{
Freshman Library Orientation: a Need for New Approaches
}

\begin{abstract}
Reevaluation of freshman library orientation programs is suggested with major emphasis on: (1) the need for a continuing four or five year orientation program; (2) increased college enrollments; (3) new media of communication; and (4) increased emphasis on the individual student. A brief historical review is presented followed by the development of the major theme. A typical, continuing four-or five-year orientation program is outlined in some detail, and the use of newer media is encouraged.
\end{abstract}

E VERY SEPTEMBER more and more college and university librarians, either by choice or consequence, are finding it necessary to reevaluate their freshman orientation procedures. Concern for present programs is being generated to a great degree by (1) the need for a four- or five-year library instruction program, a program not limited to the usual freshman orientation week; (2) increased college enrollments; (3) new media of communication; (4) increased emphasis on the individual student. These four major considerations must be incorporated into the new concepts of orientation, while still preserving the basic objective of the program.

Any library orientation program, be it for present or future consumption, should be concerned with developing a pattern of habits that will lead the in-

This paper is adapted from an address to the College and University Section, New Jersey Library Association, delivered November 14, 1964, at Fairleigh Dickinson University. Mr. Hartz is Assistant Professor of Library Science, Trenton State College. dividual to information sources that verify or extend his knowledge. At all levels of higher education new knowledge must be promptly transmitted to students and to the scholarly community. It must be verified and made meaningful in relation to existing knowledge. The quickened pace of discovery requires an equally accelerated rate of transmission, unless much of the investment in research is to be wasted through duplication. At best, no single library could ever hope to acquire the written records of all new-found knowledge; the needs of every student can never fully be met. There are too many recorded experiences and too many needs to be dealt with.

Regardless of limitations, there still remains for the library the responsibility of meeting most student needs, of helping to assure the student that he has exhausted his first available source of information before leaving his own campus to explore neighboring college, public, and research libraries.

The traditional time for conveying library information has been in the pop- 
ular freshman orientation week. Devised to give library orientation just once during one's college career, the lectures are burdened with detail and innumerable reference citations, trying to give the college freshman in one or two hours what librarians have learned in one or more years of formal training. Students find it difficult to take adequate notes to enable them later to coordinate the lectures into a meaningful experience.

Most literature agrees that the first weeks are not the best time to attempt library instruction. Students are still too preoccupied with becoming acquainted with their instructors and textbooks and making general adjustment to college life. Librarians, particularly, agree that freshman week programs are too full of many different kinds of activity to enable new students to assimilate detailed instruction in how to use the library, although they agree that some introduction to the library or invitation to visit the library should be on the program.

Research and experience have taught us that a definite need does exist for library instruction on the undergraduate level. Research has shown that undergraduates need to know how to use a library if they are going to be academically successful. There is a significant and positive relationship between knowledge of library use and academic standing. Scores made in a recent test of library skills and understanding, administered to "64 teachers' college seniors, revealed that students scoring higher than the median on the library test tended to have higher four-year course averages than those who scored below."

The revitalization of the present lagging orientation programs will depend to a large degree upon a more realistic approach to course content and presentation, improving the "what, when, and

\footnotetext{
1 W. Joyce, "Study of Academic Achievement and Performance on a Test of Library Understanding." Journal of Educational Research, LIV (January 1961), 198-9.
}

how" of the instructional presentation: What should be taught? When should it be taught? How should it be taught?

If formal instruction is used, the first phase should acquaint the student with the physical arrangement of the library, the rules and regulations, and the special collections, and should fix in his mind the general location of all major resources. Students should have opportunity to meet the staff, browse through the stacks, and actually see the vast amount of material available. This first phase of orientation should be a generally pleasant introduction to the why and what of the library rather than to how to use it.

Phase two, including methodical instruction in the use of the library, could begin when the need arises, logically at the beginning of the research paper. This would be the time to give detailed instruction on the use of the card catalog, including treatment of the more important filing rules, newspaper and periodical indexes, selected reference works, and an introduction generally to the more important reference sources. This phase can be effectively illustrated by a series of displays, strategically placed throughout the library.

Phase three of a realistic program would naturally be a continuation of phase two, but geared to the needs of advanced students. College juniors and seniors are at the peak of their need for advanced reference tools. Courses revolve around more individual study reported in term and research papers. If instruction is given only once in a student's college career-during his freshman year-by the time he enters his major field of concentration he has forgotten independent library procedures. Orientation for junior and senior students should include the use of specialized reference tools in their major fields, not only the more general information sources but the authorities and 
their contributions to the major field of study. Phase three could properly be an elective credit course taught by a member of the library staff.

This formal approach to library instruction-the type which provides appropriate materials and instruction to reach students at different periods in their college careers-is ably presented and summarized by Luella Snyder in her book The Second Kind of Knowledge. ${ }^{2}$ Miss Snyder recommends the following program:

During registration each year. A small leaflet briefly summarizing the organization of the library, location of units, special services, hours of operation, and regulations for use.

During freshman orientation. A brief, motivational presentation to awaken interest in the library and invite students to use it.

Early in the semester for all freshmen and transfers. A review of minimum skills, introduction to general reference resources, review of facilities and services of the library, and provision for students to become familiar with the various units.

Throughout the academic year. Material for independent, individual review of both basic and more advanced library resources and how they can be used to best advantage, available at all times for student use.

At time of academic specialization. An introduction to special reference materials and familiarity with departmental library, scheduled as a regular part of the academic program.

For upperclass majors and honors students. A more intensive experience to acquaint them with a wider range of

\footnotetext{
${ }^{2}$ Luella Snyder, The Second Kind of Knowledge, a special library project report to the coordinator and director of project 1 of the inter-university program in teacher education on the use of library resources by university students. Inter-University Program in Teacher Education and School of $\mathrm{Li}$ brary Science, Syracuse University (Syracuse: Syracuse University Press, 1964).
}

materials, in a workshop session on a voluntary basis but scheduled as a regular part of the academic program.

For graduate students. A seminar on reference tools in their field, and the services provided for them by the library, with attendance voluntary.

For students planning careers in research. Courses in subject matter bibliography.

Certainly a continuous four-year instructional program is the ideal, but too few college libraries have the staff for this. Giving library instruction to thousands or even hundreds of students is a monotonous and stultifying experience, consuming staff hours which could be put to more fruitful use. It has been suggested, from time to time, that faculty could assume some of the instructional responsibility. Since, however, a majority of faculty themselves have to be prodded into making better use of the library, it is doubtful whether they could stimulate better student use. In most cases staff, funds, and time for formal library instruction are still provided by the library organization.

The need for a four-year program coupled with increasing enrollments necessitates a better method of transmission.

Larger colleges and universities may use closed circuit television for teaching the use of the library. A series of television programs would certainly conserve staff. The one or two staff members presenting the program would have to work harder in preparing for the presentation, but hundreds of students could be reached in one class hour by one staff member. Additionally, television has a number of advantages as compared to the usual platform lecture and blackboard demonstration:

The television screen and the scenes depicted on it tend to draw and hold attention to the exclusion of anything that might be going on elsewhere. 
Demonstration materials-catalog cards, books, or other display materialcan be made clearly visible to every member of the audience by enlarging the object before the cameras to any desired size.

The possibility exists, when cost is not prohibitive, of video-taping a complete series of instructional lectures. This would eliminate the yearly preparation for the lectures, thus further conserving staff, time, and funds.

Another approach, especially in large universities that have film production centers, is the preparation of instructional films and filmstrips on the use of the library. Again, Miss Snyder in her book, The Second Kind of Knowledge, recommends:

A set of filmstrips on basic library skills for university freshmen, covering such topics as classification systems and the subject heading approach to knowledge, using the card catalog; types of reference works and their characteristics; parts of a book and the kind of information to be found in each part; how to write a research paper.

A film on the general principles of using a university library for research, for university freshmen and transfer students; high school students planning to go to college. This film would review the basic minimum library skills and introduce resources and skills needed by university students.

A film about how teachers and librarians can foster research skills in high school students. Basically the film would be for teachers and librarians in service; students in education and in library school. The content would show how teachers themselves can make better use of library resources, how they can foster library skills in their own students, and how teachers and librarians can cooperate in order for the library to make its maximum contribution to education.

A film to motivate students to use the library, designed for university freshmen, during freshman orientation. This film should leave the audience with the feeling that the library is an important place for them.

Thus far we have concerned ourselves with group instruction, stressing the need for presenting instructional material effectively and interestingly to large numbers of students at one time. But is this formal unsolicited instruction as valuable as the casual contacts during which learning may occur? Should the college assume the responsibility for teaching the use of the library, or should librarians provide the best service to the student who presents himself voluntarily for instruction? So many times we hear students remark: "Why weren't we told sooner?" or "If I'd only known this before I wrote my paper." Perhaps the student would have known sooner or would have known before writing his paper, if he had taken it upon himself to find out.

Lack of staff, limited time for preparation and administration of orientation courses, and diversity of subject matter are going to place more of the burden upon the student. Library instruction will become dependent upon the informal conference between student and librarian. The teaching will be done by conversation and example and by directing the student's attention to the library materials which will have immediate interest for him. By finding and identifying the facts then demanded the student teaches himself the function and limitations of each informational aid. The student engaged individually gains the sense of satisfaction and achievement that comes only through independent effort. Additionally, the pressure of increased enrollments on librarians and faculty means that students will have to learn to work independently and at a higher level of skill. 
Independent student research is not a harsh escape from the dilemma of group instruction but rather a sensible continuation of present secondary school practices. Tomorrow's entering freshmen will come from public schools which will have better and more adequate library facilities. Many will come to us with at least an introductory course in using the card catalog, knowledge of dictionaries, encyclopedias, periodical indexes, miscellaneous references, and in general how to use books. The college should no longer need to assume complete responsibility for formal library instruction, but rather for an informal and flexible program based on individual needs. The library would then truly become the core of the educational system, the cultural center of the campus, the citizen's university, or whatever else it may so glibly be called today.

\section{Conference on Library Surveys}

A CONFERENCE on library surveys will be cosponsored by the ACRL Committee on Library Surveys and Columbia University school of library service, on June 14-17. Registration fee is $\$ 65$. Inquiries and registrations should be sent to Dr. Jack Dalton, Dean, School of Library Service, Columbia University, New York, N.Y. 10027.

\section{Program:}

June 14

Welcome and Introduction; Jack Dalton, Professor Maurice F. Tauber

"The Origins and Evolution of the Library Survey," Guy R. Lyle, Emory University

"Surveying Book Collections and Other Materials," Edwin E. Williams, Harvard University Libraries, and Lewis Leary, Columbia University

June 15

"Survey of Processing," Robert Kingery, New York Public Library

"Survey of the Use of Library Resources and Facilities," Leon Carnovsky, Graduate Library School, University of Chicago

"The Library Staff: Survey of Adequacy and Competence," Lowell A. Martin, Grolier, Inc.

\section{June 16}

"Survey of Library Buildings and Facilities," Donald E. Bean, Library Building Consultants, Inc.

"Survey of Library Administration: Budget and Finance," John A. Humphry, Brooklyn Public Library

"Survey of Library Administration: Organization and Management," Stephen A. McCarthy, Cornell University

\section{June 17}

Panel Discussion: "Special Approaches and Problems of Library Surveys." Moderator: Morris A. Gelfand, Paul Klapper Library, Queens College, New York; Public libraries: Andrew Geddes, Nassau Library System; State Libraries: Walter T. Brahm, Connecticut State Library; Academic and Research Libraries: Mark M. Gormley, University of Wisconsin; School Libraries: Frances E. Henne, School of Library Service, Columbia University; Special Libraries: Janet Bogardus, Federal Reserve Bank of New York.

"The Library Survey: Its Value, Effectiveness, and Use as an Instrument of Administration," E. W. Erickson, Mark Jefferson Library, Eastern Michigan University

Concluding Remarks: Professor Tauber

Lectures and panel discussion will be followed by discussion periods. 